\title{
VirB10 vaccination for protection against Anaplasma phagocytophilum
}

\author{
Francy L. Crosby ${ }^{*}$ D, Anna M. Lundgren, Carol Hoffman, David W. Pascual and Anthony F. Barbet
}

\begin{abstract}
Background: Human granulocytic anaplasmosis (HGA) is a tick-borne disease caused by the etiologic agent Anaplasma phagocytophilum. HGA was designated a nationally notifiable disease in the United States in 1998. Currently there are no vaccines available against HGA. Conserved membrane proteins that are subdominant in Anaplasma species, such as VirB9 and VirB10, may represent better vaccine targets than the variable immunodominant surface proteins. VirB9 and VirB10 are constituents of the Type 4 secretion system (T4SS) that is conserved amongst many intracellular bacteria and performs essential functions for invasion and survival in host cells.

Results: Immunogenicity and contribution to protection, provided after intramuscular vaccination of plasmid DNA encoding VirB9-1, VirB9-2, and VirB10 followed by inoculation of homologous recombinant proteins, in a prime-boost immunization strategy was evaluated in a murine model of HGA. Recombinant VirB9-1-, VirB9-2-, and VirB10-vaccinated mice developed antibody responses that specifically reacted with A. phagocytophilum organisms. However, only the mice vaccinated with VirB10 developed a significant increase in IFN- $\gamma \mathrm{CD}^{+} \mathrm{T}$ cells and partial protection against challenge with A. phagocytophilum.

Conclusions: This work provides evidence that A. phagocytophilum T4SS VirB10 is partially protective in a murine model against infection in an IFN- $\gamma$-dependent fashion and suggests that this protein may be a potential vaccine candidate against this and possibly other pathogenic bacteria with a T4SS.
\end{abstract}

Keywords: Anaplasma phagocytophilum, Gram-negative bacterium, T4SS, VirB10 vaccination, DNA vaccine, Recombinant protein vaccine, Prime-boost immunization

\section{Background}

The order Rickettsiales, of which A. phagocytophilum is a member, includes numerous pathogens of humans and animals and agents requiring high containment because of the risk of spread. Many of these infections are difficult to diagnose because of non-specific disease symptoms. Few effective vaccines are available for this group of organisms, although strong immunity can develop in humans and animals that have been infected and recovered [1]. Vaccination has been problematic because of strain or antigenic variation of immunodominant outer membrane proteins. It has been proposed that better vaccine targets are subdominant, conserved proteins that have not been the primary targets of

\footnotetext{
* Correspondence: crosbyl@ufl.edu

Department of Infectious Diseases and Immunology, College of Veterinary Medicine, University of Florida, 2015 SW 16th Avenue, Gainesville, FL 32608, USA
}

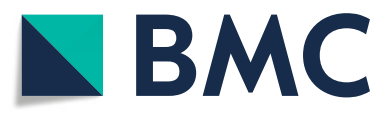

(c) The Author(s). 2018 Open Access This article is distributed under the terms of the Creative Commons Attribution 4.0 International License (http://creativecommons.org/licenses/by/4.0/), which permits unrestricted use, distribution, and reproduction in any medium, provided you give appropriate credit to the original author(s) and the source, provide a link to the Creative Commons license, and indicate if changes were made. The Creative Commons Public Domain Dedication waiver (http://creativecommons.org/publicdomain/zero/1.0/) applies to the data made available in this article, unless otherwise stated.

immune selection [2-5]. Components of the Type 4 Secretion System (T4SS) make good vaccine candidates due to their subdominant nature $[6,7]$. The T4SS is a multiprotein complex that forms membrane channels required for the translocation of virulent substrates that enable colonization and survival of bacteria in the host cells. Although all Rickettsiales have a T4SS [8], immune responses against these components have been most extensively investigated in the bovine pathogen Anaplasma marginale [6, 9-15]. Cattle vaccinated with $A$. marginale outer membranes are protected against infection and respond strongly to membrane protein components. These responses are made against immunodominant, antigenically variable proteins as well as against VirB9 and VirB10 components of the T4SS [13]. Outer membrane protein vaccination of cattle induces strong IgG2 and $\mathrm{CD}^{+} \mathrm{T}$ cell proliferative and IFN- $\gamma$ responses against VirB9 and VirB10 $[6,9]$. Recently, a study tested the immunogenicity of recombinant $A$. marginale VirB9-1 and 
VirB9-2 in C57BL/6 J mice and indicated that these proteins also elicited strong humoral and T-cell mediated responses [16].

Sera from dogs experimentally infected with Ehrlichia canis reacted with recombinant VirB9, demonstrating that this protein is also immunogenic in organisms of this species [17]. There is evidence that in Rickettsiales VirB9 may be surface-exposed on outer membranes [18, 19]. A comparative genomics study of seven strains of $A$. phagocytophilum was recently done showing that VirB9 and VirB10 are conserved between strains, unlike other T4SS components such as VirB2 and VirB6. There are two VirB9 paralogs, VirB9-1 and VirB9-2, both notably having predicted signal peptides. Of all the potentially exposed components of the T4SS, VirB9 and VirB10 are the least diverse among strains [18]. Herein, we queried whether soluble recombinant protein analogs of VirB9 and VirB10 might confer protective immunity against A. phagocytophilum in a mouse model.

\section{Results}

Preparation of soluble recombinant VirB9-1, VirB9-2 and VirB10 proteins for immunization

Recombinant VirB9-1, VirB9-2, and VirB10 were cloned and expressed as his-tag fusions in E. coli. We developed a method that resulted in the production of recombinant antigens that did not require purification from inclusion bodies or additional solubilization and refolding steps that possibly might affect the recovery of a functional protein. Soluble fractions of recombinant VirB9-1, VirB9-2, and VirB10 before and after nickel column purification were analyzed by Coomassie blue-stained SDS-PAGE gels, and the expected sizes plus his-tags were confirmed by Western blot (Fig. 1). These optimized culture conditions resulted in the production of adequate yields of soluble recombinant proteins suitable for the vaccination experiments. The recombinant proteins were of the sizes expected, with the exception of VirB10 where there were a series of fragments reactive with anti-his tag antibody up to and including the expected size of $52 \mathrm{KDa}$. These may represent proteolytic degradation fragments of VirB10.

\section{Anaplasma phagocytophilum VirB9-1, VirB9-2, and VirB10 induce elevated antibody titers in mice}

Five groups of mice were primed with the individual eukaryotic DNA expression plasmids encoding $A$. phagocytophilum VirB9-1, VirB9-2, or VirB10, their combination, or empty $p c D N A 3.1$ vector followed by boost with their respective recombinant proteins, or for the negative control, ovalbumin. First, serial dilutions of pooled sera from the three mice per group sacrificed before challenge were tested by IFA using A. phagocytophiluminfected HL-60 cells as a source of antigen. Red fluorescent inclusions corresponding to vacuoles filled with $A$. phagocytophilum organisms (morulae) were detected using sera from all VirB-vaccinated but not from control mice (data not shown).

These sera were also assayed by Western blot of proteins from equal amounts of host cell-free A. phagocytophilum organisms (Fig. 2). Results show that sera from mice vaccinated with rVirB9-1, rVirB9-2, rVirB10, and (rVirB9-1-rVirB9-2-rVirB10) mix reacted with proteins of molecular sizes that corresponded to $A$. phagocytophilum VirB9-1, VirB9-2, and VirB10. In contrast, ( $p c D N A 3.1 /$ Ovalbumin)-vaccinated mice did not develop antibodies against the same size proteins.

We used ELISA to quantify $A$. phagocytophilum VirB9-1, VirB9-2 and VirB10-specific antibodies in sera from all 10 vaccinated mice in each group before challenge. As antigen, we used host cell-free A. phagocytophilum organisms $\left(10^{8}\right)$ applied to each well of ELISA plates. Vaccination with rVirB9-1, rVirB9-2, rVirB-10 and (rVirB9-1-rVirB9-2-rVirB10) mix induced the production

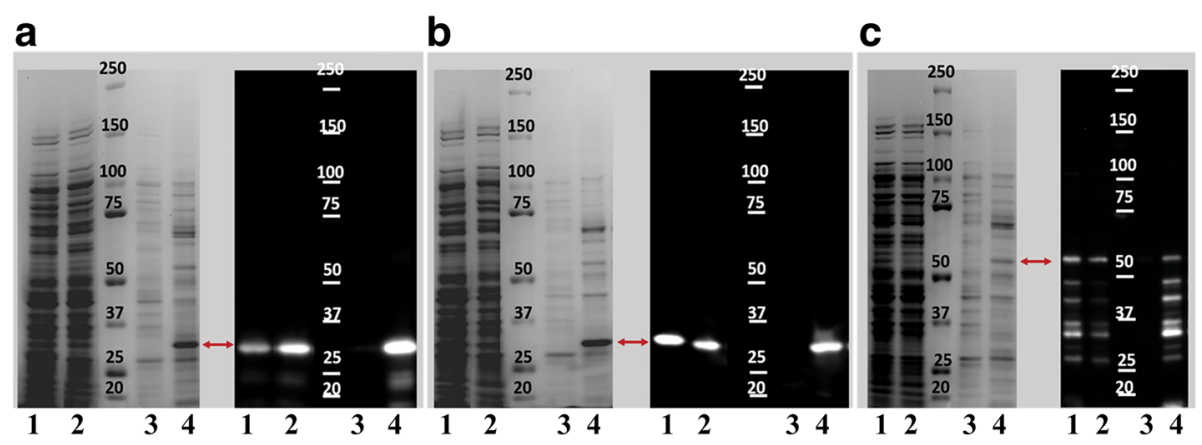

Fig. 1 Analysis of the recombinant proteins VirB9-1, VirB9-2 and VirB10. SDS-PAGE and Western Blot analysis of recombinant VirB9-1 (a), VirB9-2 (b), and VirB10 (c). Lanes represent the different fractions analyzed during the purification procedure, $1=$ Total crude protein, $2=$ Filtered supernatant fraction obtained after high-speed centrifugation, 3 = Washed fraction, 4 = Eluted protein. Western Blot analysis was performed using the monoclonal anti-histidine tag antibody reacting with the recombinant protein (red arrows). Predicted molecular weights plus tags for VirB9-1 (33.5KDa), VirB9-2 (31.6KDa) and VirB10 (52KDa) 


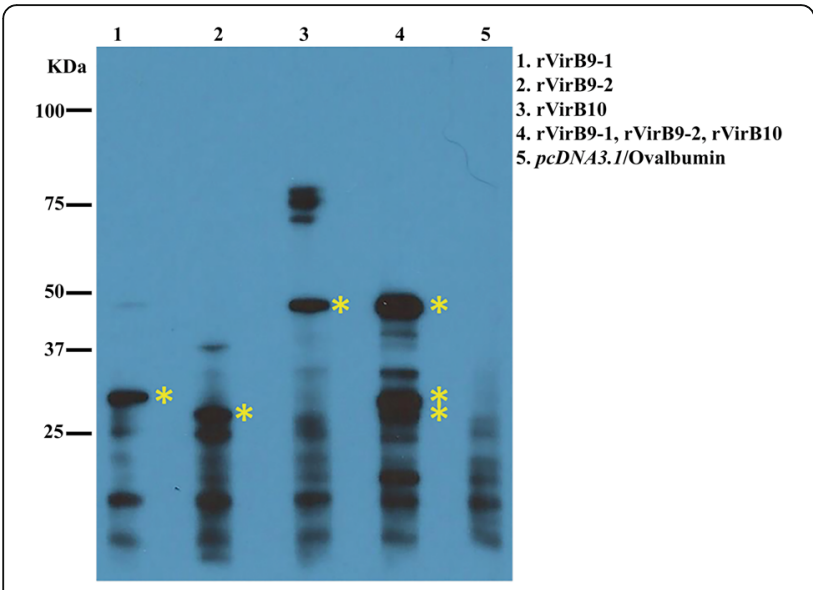

Fig. 2 Sera from $\mathrm{C} 3 \mathrm{H} / \mathrm{HeN}$ immunized mice reacted against A. phagocytophilum VirB9-1, VirB9-2, and VirB10 proteins. Proteins from equal amounts $\left(10^{8}\right)$ of host cell-free $A$. phagocytophilum were separated by SDS-PAGE gel electrophoresis. Immunoblots of transferred proteins were reacted with pooled sera from the 3 immunized but not challenged mice (1:1000) and reactions were visualized by chemiluminescence. The sizes of protein standards are indicated on the left in $\mathrm{kDa}$. Predicted molecular weights for A. phagoytophilum VirB9-1 (30.5KDa), VirB9-2 (28.6KDa), and VirB10 (49.2KDa). Bands of similar sizes were not visualized in sera from the pCDNA3.1/Ovalbumin control group

of significantly higher antibody titers against $A$. phagocytophilum organisms relative to (pcDNA3.1/Ovalbumin)vaccinated mice (Fig. 3). The endpoint mean titers based on this assay were (Mean \pm SEM) $345 \pm 114.1,450 \pm 143.1$, $390 \pm 114.4$ and $375 \pm 100.6$ in rVirB9-1, rVirB9-2, rVirB10 and (rVirB9-1-rVirB9-2-rVirB10)-vaccinated mice respectively.

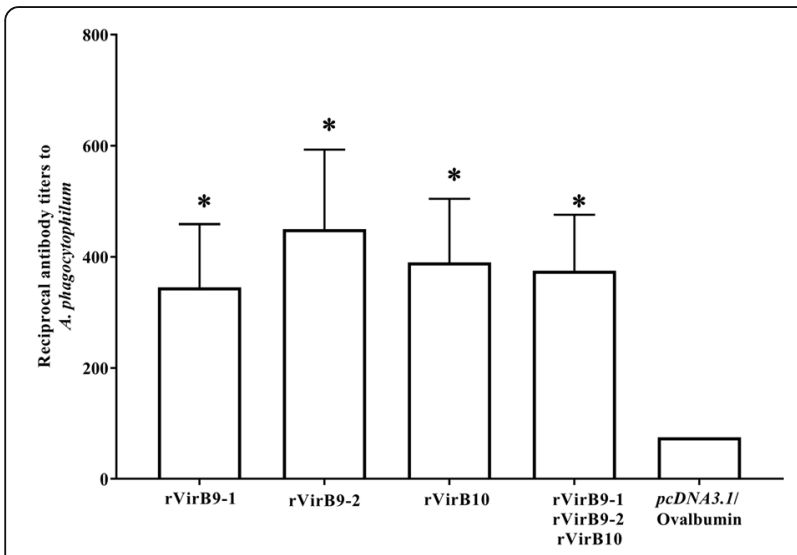

Fig. 3 Anti-A. phagocytophilum antibody titers. Sera from all 10 immunized and control mice in each group were collected before challenge at two weeks after the last immunization. Endpoint titers were evaluated by ELISA. ${ }^{*}, P<0.05$

\section{VirB10 confers partial protection against $A$.}

\section{phagocytophilum challenge}

To evaluate protective efficacy of rVirB9-1, rVirB9-2, rVirB10 and the mixture of the three subunits against A. phagocytophilum challenge, we infected rVirB-vaccinated and irrelevant antigen-vaccinated mice (7/group) with one dose of isolated organisms from $5.63 \times 10^{5} \mathrm{HL}-60$ infected cells ( $90 \%$ of the cells contained morulae). Bacteria loads in blood following challenge were quantitated by real time qPCR assay targeting the single copy gene $m s p 5$ to determine the number of $A$. phagocytophilum genome equivalents (GE). This assay detected maximum bacterial loads in all groups at day 8 post infection. However, only in the group of mice vaccinated with rVirB10, bacteria replicated to significantly lower levels (Mean \pm SEM peak bacterial load of $530 \pm 159.9, P=0.032)$ than in the ( $p c D N A 3.1 /$ Ovalbumin)-vaccinated mice (Mean \pm SEM peak bacterial load of $1380 \pm 311.6$ ) (Fig. 4). Moreover, two mice from the rVirB10 group cleared the infection, as we did not detect A. phagocytophilum at any time post-challenge. Although the bacterial loads in the groups of mice vaccinated with rVirB9-1, rVirB9-2 and the (rVirB9-1-rVirB9-2-rVirB10) mix were lower than the control group, this reduction was not significant.

To assess the correlation between anti- $A$. phagocytophilum VirB9-1, VirB9-2 and VirB10 antibody titers produced before challenge and protection against $A$. phagocytophilum, the ELISA endpoint titers were plotted as a function of the bacteria loads. Pearson's correlation tests for all 7 vaccinated and challenged mice in each group showed no correlation between reduced bacterial loads and antibody titers.

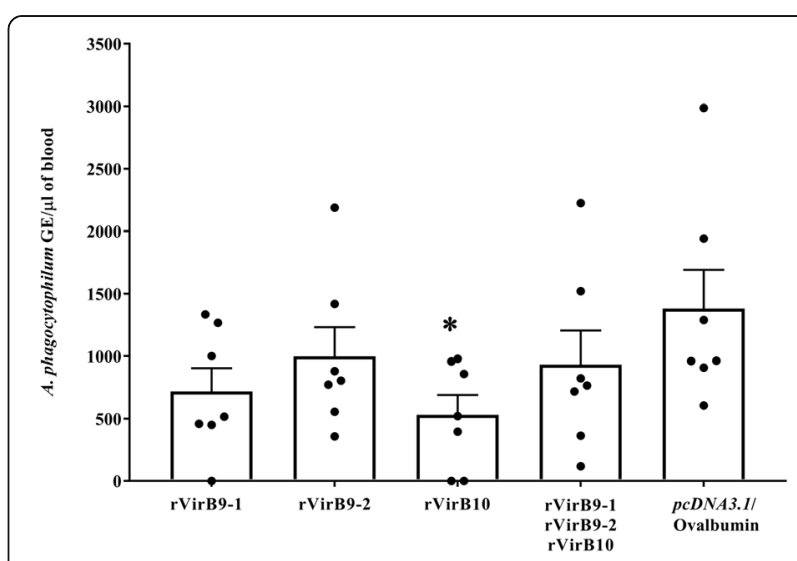

Fig. 4 Immunization with rVirB10 confers partial protection against A. phagocytophilum challenge. A. phagocytophilum GE means at the peak of infection (day 8 post-challenge). Each symbol represents the value for an individual mouse. ${ }^{*}, P<0.05$ 


\section{VirB10 induces $\mathrm{CD}^{+}$Th1 immune responses in vaccinated mice}

To evaluate $\mathrm{T}$ cell responses to total $A$. phagocytophilum proteins, as source of VirB9-1, VirB9-2 and VirB10, splenic lymphocytes from the different vaccination groups were analyzed by flow cytometry before and after challenge. Before challenge, the rVirB10-vaccinated mice were the only group that stimulated antigen-specific $\mathrm{CD}^{+} \mathrm{T}$ cell responses that were characterized by 2.6-fold higher numbers of IFN- $\gamma^{+} \mathrm{CD} 4^{+} \mathrm{T}$ cells than the irrelevant antigen ( $p c D N A 3.1 /$ Ovalbumin)-vaccinated mice (Fig. 5a, b). No significant differences in the numbers of $\mathrm{IL}-10^{+}$and double-positive (IL- $10^{+}-\mathrm{IFN}-\gamma^{+}$) $\mathrm{CD}^{+}{ }^{+} \mathrm{T}$ cells in any of the rVirB-immunized mice compared to the ( $p c D N A 3.1 / \mathrm{Ovalbumin}$ )-vaccinated mice were observed. In contrast, rVirB9-1, rVirB9-2 and (rVirB9-1-rVirB9-2-rVirB10)-vaccinated mice, but not those vaccinated with $\mathrm{rVirB10}$, stimulated $\mathrm{CD}^{+} \mathrm{T}$ cells. This was indicated by 4.36, 2.7 and 5.09-fold increase in the numbers of IFN- $\gamma^{+} \mathrm{CD}^{+} \mathrm{T}$ cells in mice vaccinated with rVirB9-1, rVirB9-2, and the (rVirB9-1-rVirB9-2-rVirB10) mix, respectively, when compared to (pcDNA3.1/
Ovalbumin)-vaccinated mice (Fig. 5c). Likewise, mice vaccinated with the (rVirB9-1-rVirB9-2-rVirB10) mix had 5.0-fold higher numbers of $\mathrm{IL}-10^{+} \mathrm{CD}^{+} \mathrm{T}$ cells relative to ( $p c D N A 3.1 /$ Ovalbumin)-vaccinated mice (Fig. 5c). So, vaccination with $\mathrm{rVirB10}$ induced IFN $-\gamma^{+} \mathrm{CD}_{4}^{+} \mathrm{T}$ cells while vaccination with rVirB9-1, rVirB9-2 and these two in combination with rVirB10 induced IFN- $\gamma^{+}$or IL- $10^{+} \mathrm{CD}^{+}$ T cells.

After $A$. phagocytophilum challenge, distinct antigen-specific $\mathrm{T}$ cell responses were observed mainly in rVirB9-1 and rVirB10-vaccinated mice. Again, mice vaccinated with rVirB10 displayed better $\mathrm{CD}^{+} \mathrm{T}$ cell responses to total bacterial antigens, not only by maintaining elevated numbers (2.7-fold) of IFN- $\gamma^{+} \mathrm{CD}^{+} \mathrm{T}$ cells, but also with a 10.9 and 2.1 -fold expansion in the numbers of $\mathrm{IL}-10^{+}$and double-positive (IL- $10^{+}$-IFN- $\gamma^{+}$) $\mathrm{CD}^{+}{ }^{+} \mathrm{T}$ cells, respectively, when compared to ( $p c D N A 3.1 /$ Ovalbumin)-vaccinated mice (Fig. 6a, b). Contrary to that observed before challenge, mice vaccinated with rVirB9-1 also stimulated $\mathrm{CD}^{+} \mathrm{T}$ cells as evidenced by 15.6 -fold greater numbers of $\mathrm{IL}-10^{+} \mathrm{CD} 4^{+} \mathrm{T}$ cells relative to the ( $p c D N A 3.1 / \mathrm{Ovalbumin})$-vaccinated mice (Fig. 6b). Interestingly, the $\mathrm{IL}-10^{+} \mathrm{CD} 4 \mathrm{~T}$ cell

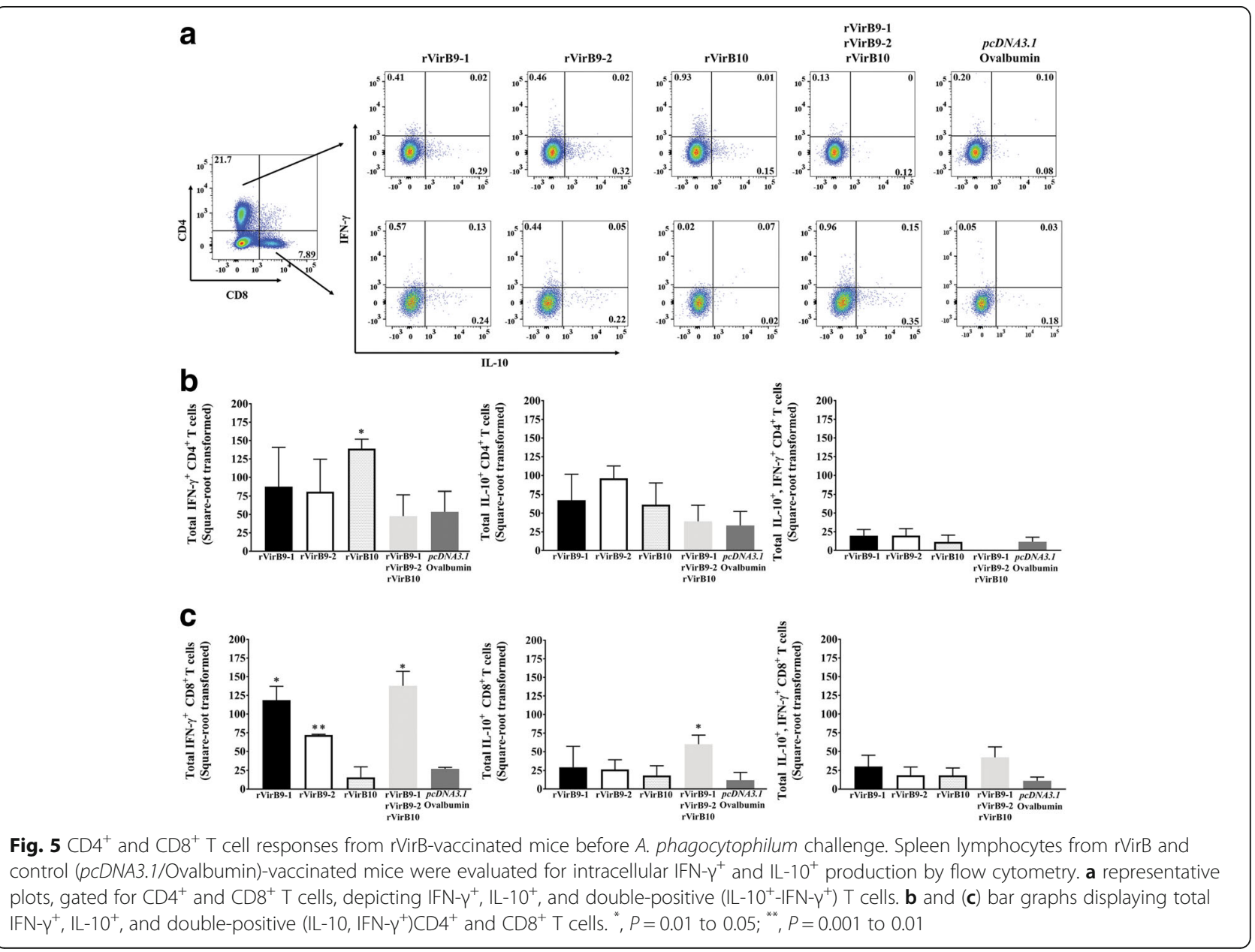




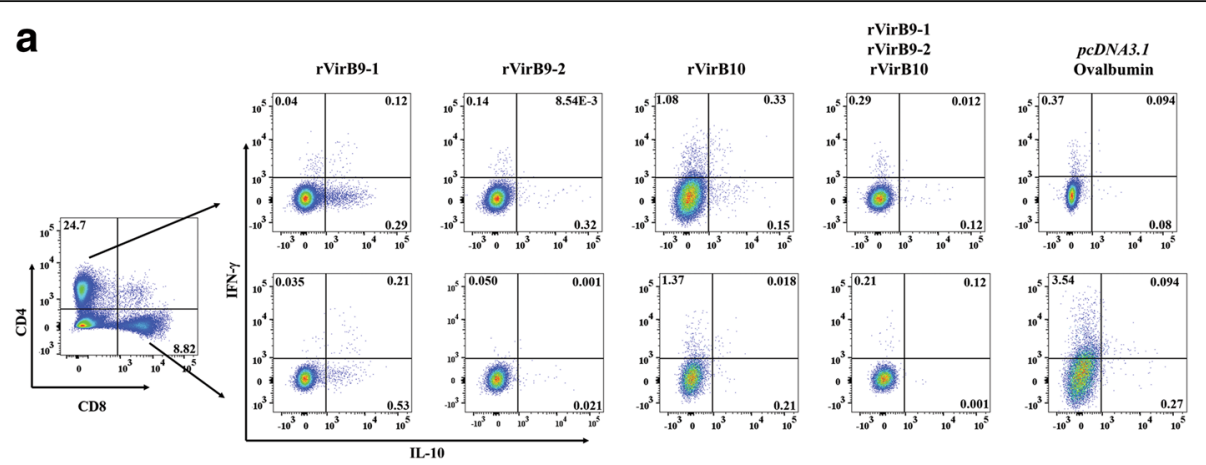

b
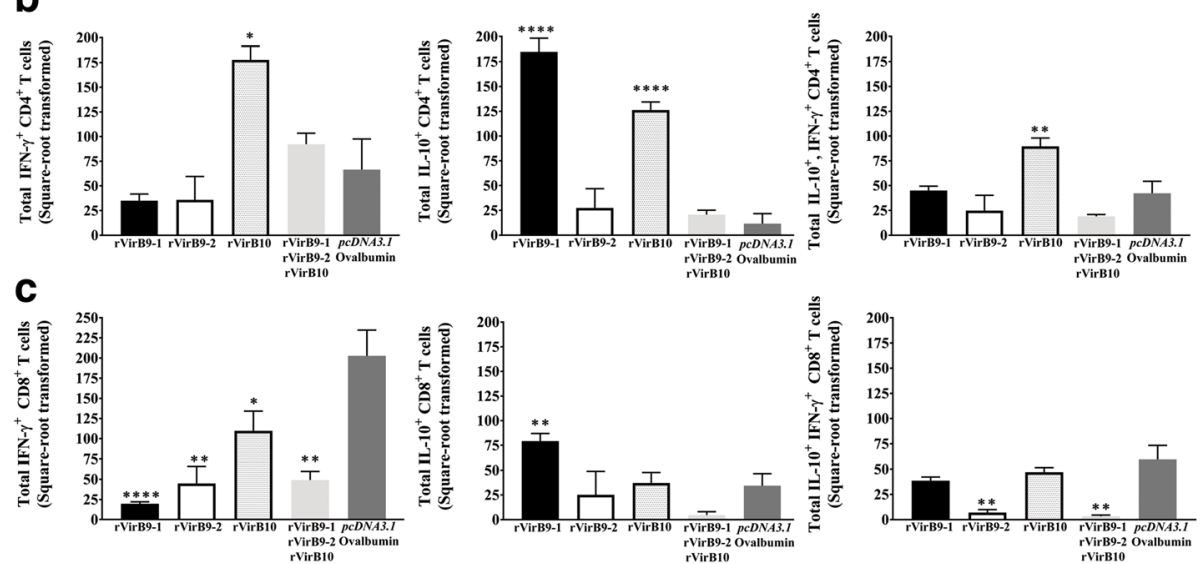

Fig. $6 \mathrm{CD}^{+}$and $\mathrm{CD} 8^{+} \mathrm{T}$ cell responses from rVirB-vaccinated mice after A. phagocytophilum challenge. Spleen cells from rVirB and control (pcDNA3.1/Ovalbumin)-vaccinated mice were evaluated for intracellular IFN- $\gamma^{+}$and IL-10 $0^{+}$production by flow cytometry. a representative plots,

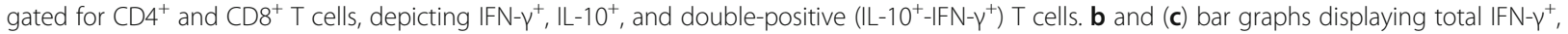
$\mathrm{IL}-10^{+}$, and double-positive (IL-10+ $\left.0^{+}, \mathrm{FN}-\gamma^{+}\right) \mathrm{CD} 4^{+}$and $\mathrm{CD} 8^{+}$T cells. ${ }^{*}, P=0.01$ to $0.05 ;^{* *}, P=0.001$ to $0.01 ;{ }^{* * * *}, P<0.0001$

numbers from rVirB9-1-vaccinated mice exceeded IFN- $\gamma^{+}$ CD4 $\mathrm{T}$ cell numbers from the same group by $5.26-$ fold $(P<0.0001)$. However, IFN $-\gamma^{+} \mathrm{CD} 4^{+} \mathrm{T}$ cell numbers from rVirB10-vaccinated mice were 1.4 -fold $(P<0.01)$ above the same group's IL- $10^{+} \mathrm{CD} 4^{+} \mathrm{T}$ cell numbers.

Conversely, the numbers of antigen-specific IFN- $\gamma$ $\mathrm{CD}^{+} \mathrm{T}$ cells were significantly reduced by $10.3,4.5,1.8$ and a 4.8-fold in rVirB9-1, rVirB9-2, rVirB10 and (rVirB9-1rVirB9-2-rVirB10)-vaccinated mice, respectively, compared to the ( $p c D N A 3.1 /$ Ovalbumin)-vaccinated mice (Fig. 6c). However, only rVirB9-1 vaccination induced significant numbers of IL-10 $\mathrm{CD}^{+} \mathrm{T}$ cells, with 2.3-fold higher numbers than in ( $p c D N A 3.1 /$ Ovalbumin)-vaccinated mice (Fig. 6c).

These results indicate that after $A$. phagocytophilum challenge rVirB10 continued to specifically stimulate $\mathrm{CD} 4^{+} \mathrm{T}$ cells through a better response characterized by elevated numbers of IFN- $\gamma^{+}, \mathrm{IL}-10^{+}$and double-positive $\left(\mathrm{IFN}-\gamma^{+}-\mathrm{IL}_{-10^{+}}\right) \mathrm{CD}^{+} \mathrm{T}$ cells. Yet, rVirB9-1 induced a prominent IL-10 immune response in both $\mathrm{CD} 4^{+}$and $\mathrm{CD}^{+} \mathrm{T}$ cells, while the IFN- $\gamma^{+} \mathrm{CD}^{+} \mathrm{T}$ cell responses induced by rVirB9-1 and rVirB9-2 before challenge were abrogated.

\section{Discussion}

There are several A. phagocytophilum strains with unique adaptations to different host species, pathogenicity, clinical presentation, and immunological responses $[20,21]$. Despite their diversity, a common element in all A. phagocytophilum strains sequenced to date is the presence of genes encoding components of the T4SS prototypical to the VirB/VirD system of Agrobacterium tumefaciens. Comparative genomics of several $A$. phagocytophilum strains to define the structure of the T4SS identified that VirB9 and VirB10 are the most conserved [18]. VirB9 and VirB10 are also conserved among other species of the order Rickettsiales and although subdominant in natural infections, these proteins induce responses when outer membranes are used to immunize animals $[6,9-11,13,17]$. Hence, their conserved nature and possible role in pathogenesis make them ideal candidates for vaccine development.

In this work, we tested the ability of recombinant VirB9-1, VirB9-2, and VirB10 (alone or combined) to stimulate protective immunity against $A$. phagocytophilum in $\mathrm{C} 3 \mathrm{H} / \mathrm{HeN}$ mice. We prepared DNA vaccine constructs 
encoding VirB9-1, VirB9-2, and VirB10 as well as their respective recombinant proteins, and used them in a prime-boost immunization regimen. This vaccination approach has proven to improve and broaden protective immune responses against a wide range of pathogens [22-28] including bacterial species of the order Rickettsiales, such as Rickettsia conorii, Rickettsia rickettsii [29]. Ehrlichia ruminantium [30], Ehrlichia muris [31], and Anaplasma marginale [32].

The antigenic structure of a recombinant protein does not always mimic that of the homologous protein in its native environment, especially of membrane proteins produced as insoluble inclusion bodies that require refolding and solubilization [33, 34]. We, therefore, prioritized maintaining solubility of the recombinant VirB's during expression and purification over their yield. Considering the importance of assessing if a recombinant antigen retains epitopes similar to the native protein in the infective form of the pathogen [35-37], we aimed to evaluate humoral and cellular responses from recombinant VirB9-1, 9-2 and VirB10 vaccinated mice wherever possible directly against $A$. phagocytophilum organisms. This was done by using purified organisms from cell cultures as antigen on ELISA plates in antibody testing and as stimulating antigen in cellular immune response assays. This approach should limit the potential detection of responses against $E$. coli contaminants present in the immunizing recombinant antigens. However, we recognize the potential significance of $E$. coli contaminants and of VirB10 fragments (such as those seen in Fig. 1c) possibly contributing to immune stimulation. This requires further investigation and replication, particularly in outbred animal populations with more heterogeneous responses.

We evaluated antibody responses to rViB9-1, rVirB9-2, and rVirB10 and established that vaccinated mice developed elevated levels of antibodies that specifically reacted with native VirB9-1, VirB9-2, and VirB10 proteins. Yet, there was a lack of correlation between antibody titers against native VirB proteins from A. phagocytophilum and protection against infection. There is evidence that in Rickettsiales, antibodies bind to surface exposed antigens required for initial stages of infection (attachment to the host cell), or during intercellular spreading, to block infection [4, 38-40]. Also, BlastP searches showed significant homology between VirB10 of A. phagocytophilum and $E$. coli (E value of $3 \mathrm{e}-18,32 \%$ identity). In $E$. coli, two $\alpha$-helices in the C-terminal domain of VirB10 (the "antennae") are exposed to the extracellular environment at the top of the T4SS pore [41]. Therefore, it is possible that vaccination elicited weak or very low levels of antibodies that bind to exposed or neutralization-sensitive epitopes to prevent infection of susceptible cells. Such anti-VirB10 antibodies might not be apparent in the ELISA used in
Fig. 3 which assayed for total organism-binding antibodies. Possibly, predicted extracellular domains of $A$. phagocytophilum VirB10, could be included in the design of epitope-based vaccines also targeting other surface exposed molecules such as outer membrane protein A, Asp14 and AipA [39, 40, 42, 43].

Examination of the induced $\mathrm{T}$ cell responses to these different VirB proteins revealed a dichotomy in their ability to elicit IFN- $\gamma$ responses. IFN $\gamma$ is a Th1 cell-promoting factor important for immune protection against intracellular pathogens including $A$. phagocytophilum [44-46]. Prior to challenge, mice vaccinated solely with VirB10 induced an elevated IFN $-\gamma^{+} \mathrm{CD} 4^{+} \mathrm{T}$ cell response following restimulation with whole $A$. phagocytophilum as a source of VirB10. In contrast, the same group of mice showed a weak IFN- $\gamma^{+} \mathrm{CD}^{+} \mathrm{T}$ cell response suggesting that the dominant immunogenic peptides for VirB10 are recognized by $\mathrm{CD} 4^{+} \mathrm{T}$ cells. Mice vaccinated with rVirB9-1, rVirB9-2, or both proteins combined with rVirB10 showed no significant differences in their IFN $-\gamma^{+}$ $\mathrm{CD}^{+} \mathrm{T}$ cells from vector control mice prior to challenge. However, the same was not true for their respective $\mathrm{CD}^{+} \mathrm{T}$ cell responses since both rVirB9-1- and rVirB9-2-immunized groups showed significantly greater IFN- $\gamma^{+} \mathrm{CD}^{+} \quad \mathrm{T}$ cells than vector control or rVirB10-immunized mice. In fact, the mice immunized with all 3 proteins also showed an elevated IFN $-\gamma^{+} \mathrm{CD}^{+}$ $\mathrm{T}$ cell response implicating the contributions by $\mathrm{rVirB9}-1$ and rVirB9-2 immunogens.

In mice infected with $A$. phagocytophilum, $\mathrm{CD} 4^{+}$ $\mathrm{T}$ cells are critical for the clearance of bacteria [44, 47]. Several studies have shown that, during the initial stages of $A$. phagocytophilum infection, IFN- $\gamma$-deficient mice or IFN- $\gamma$ receptor-deficient mice developed increased bacterial loads in blood and tissues compared to immunocompetent mice, indicating the importance of this cytokine in the control of bacteremia [44, 47, 48]. Our results show that following $A$. phagocytophilum challenge, only mice vaccinated with recombinant VirB10 were protected, as evidenced by the significant reduction in the A. phagocytophilum burden. Such protection was associated with increased levels of IFN- $\gamma^{+} \mathrm{CD} 4^{+} \mathrm{T}$ cells induced by VirB10 since mice immunized with rVirB9-1, rVirB9-2, or all three proteins did not have significant reductions in their $A$. phagocytophilum burdens nor showed elevations in their IFN $-\gamma^{+} \mathrm{CD} 4^{+} \mathrm{T}$ cells. In contrast, the $\mathrm{CD}^{+} \mathrm{T}$ cell responses elicited by rVirB9-1, rVirB9-2, or all three proteins resulted in reduced IFN- $\gamma^{+}$cells. Why rVirB9-1 and rVirB9-2 were less effective immunogens may be tied to their ability to stimulate IL-10 either in preference to IFN- $\gamma$ or to regulate IFN- $\gamma$ responses. IL-10 is associated with immunoregulation of the host response dampening inflammatory responses including IFN- $\gamma$ [49], and there is evidence 
that during HGA IL-10 has an anti-inflammatory role $[21,48,50]$.

The present work demonstrates stimulation of different host responses, either $\mathrm{CD} 4^{+}$or $\mathrm{CD}^{+} \mathrm{T}$ cell-dependent and their uniquely associated cytokines. In this regard, while none of the groups showed a predilection for IL-10 production by the induced $\mathrm{CD} 4^{+}$or $\mathrm{CD} 8^{+} \mathrm{T}$ cells prior to challenge, the rVirB9-1-vaccinated mice showed the greatest $\mathrm{IL}-10^{+} \mathrm{CD}^{+}$and $\mathrm{CD} 8^{+} \mathrm{T}$ cell responses subsequent to challenge. This $\mathrm{IL}-10^{+} \mathrm{CD} 4^{+} \mathrm{T}$ cell response was greater than the one induced in rVirB10-vaccinated mice. Therefore, IL-10 seems to dampen the induced, elevated IFN $-\gamma^{+}$ $\mathrm{CD}^{+}{ }^{+} \mathrm{T}$ cell response, which is induced by vaccination with VirB10 alone. This is further suggested by the increased presence of double-positive $\left(\mathrm{IFN}-\gamma^{+} \mathrm{IL}^{-10^{+}}\right) \mathrm{CD}^{+}$ T cells. Double-positive (IL- $10^{+}$-IFN- $\left.\gamma^{+}\right) \mathrm{CD} 4^{+} \mathrm{T}$ cells have been found during chronic infections caused by other intracellular pathogens such as Leishmania spp., Trypanosoma spp., Mycobacterium tuberculosis, and Borrelia burgdorferi and although their presence might contribute to persistence, it could also prevent collateral immune damage [51].

Studies of $A$. phagocytophilum infections in humans, mice and horses have shown that IFN- $\gamma$ is also implicated in the development of tissue lesions due to overactive inflammatory responses, showing a dual role for this cytokine [44, 48, 52-54]. However, it is also known that the anti-inflammatory effect of IL-10 helps to decrease pathology during HGA [21, 48, 53]. For example, IFN- $\gamma$-deficient mice infected with $A$. phagocytophilum had higher bacterial burdens in blood and tissues than IL-10-deficient and parental wild-type mice but minimal histopathological lesions, while A. phagocytophilum infected IL-10-deficient mice developed severe histopathological lesions [48]. In humans with HGA, mild clinical manifestations and recovery from infection is temporally associated with a dominant IFN- $\gamma$ immune response and moderate levels of IL-10 [48, 55]. Lastly, treatment of horses infected with A.phagocytophilum with the anti-inflammatory glucocorticoid dexamethasone resulted in an increased IL-10:IFN- $\gamma$ ratio and higher bacterial loads than untreated animals, but reduced disease severity [53].

An adequate balance between pro- and anti-inflammatory responses may well result in an effective control against infection while restricting tissue damage [56]. Our results show that VirB10-induced production of IFN- $\gamma$ and IL-10 might modulate the balance between immunopathological responses and control of infection. Collectively, these data show the immunogenicity of VirB10 favors protection while immunity to VirB9-1 and VirB9-2 failed to stimulate significant IFN- $\gamma$ responses and may not be important for protection.
Intriguingly, only VirB9-1, VirB9-2, and in combination with VirB10 induced increased IFN- $\gamma$-producing $\mathrm{CD}^{+} \mathrm{T}$ cells in immunized mice before challenge. However, after challenge, these levels significantly dropped relative to the control suggesting that these may be inhibited during the challenge. The importance of $\mathrm{CD}^{+}{ }^{+} \mathrm{T}$ cells for protection against $A$. phagocytophilum may be less. It has been previously shown that $\mathrm{CD} 8^{+}$ $\mathrm{T}$ cells were not essential for controlling $A$. phagocytophilum infection because MHC class I-deficient mice were as competent in eliminating the pathogen as wild-type mice $[47,54,57]$. Rather, $\mathrm{CD}_{4}^{+} \mathrm{T}$ cells are necessary in mice for effective control of $A$. phagocytophilum infection because in the absence of MHC class II-restricted $\mathrm{CD}^{+}{ }^{+} \mathrm{T}$ cells they failed to clear A. phagocytophilum [47, 54, 57].

\section{Conclusions}

In conclusion, we show that prime-boost vaccination with VirB10, a subdominant conserved antigen that is a component of the T4SS, not only induced antigen-specific humoral and $\mathrm{T}$ cell mediated responses, but also elicited partial protection against $A$. phagocytophilum challenge.

\section{Methods}

\section{Preparation of DNA vaccine constructs}

The open reading frames of $A$. phagocytophilum virB9-1, virB9-2 (devoid of their signal peptides), and virB10 genes were amplified by PCR using the Taq DNA polymerase (ThermoFisher Scientific) and cloned into $p c D N A 3.1 / C T-G F P-T O P O$ vector for high-level expression in mammalian hosts (ThermoFisher Scientific). The primers were designed to allow in frame translational fusions of these genes with the green fluorescent protein (GFP) at the C-terminal end under the regulation of the cytomegalovirus (CMV) promoter (Table 1).

Purified PCR products were ligated into pcDNA3.1/ CT-GFP-TOPO vector and transformed into TOP10 Escherichia coli cells (ThermoFisher Scientific). Individual recombinant plasmids were analyzed by sequencing to determine the presence and correct orientation of inserts. Desired clones were transfected into RF/6A endothelial cells using Lipofectamine 2000 transfection reagent (ThermoFisher Scientific), according to the manufacturer's instructions. Briefly, $0.5 \mu \mathrm{g}$ of recombinant plasmid DNA in Opti-MEM reduced serum medium (ThermoFisher Scientific) was mixed with Lipofectamine 2000 and incubated for $5 \mathrm{~min}$ before adding to each well of a twenty four well plate containing nearly confluent cell monolayers. To evaluate transfection efficiency and GFP expression, $p c D N A 3.1 / \mathrm{CT}-\mathrm{GFP}$ and mock DNA-lipofectamine mixture were used as positive and negative controls, respectively. At $48 \mathrm{~h}$ post-transfection, 
Table 1 Oligonucleotides used in this study

\begin{tabular}{|c|c|c|}
\hline & & Target \\
\hline \multicolumn{3}{|c|}{ DNA vaccines } \\
\hline AB1656 & GCCACCATGAGCACAAATATTGGCGTACC & virB9-1 \\
\hline AB1657 & GACTAAGAGCCTGATTCACAACTTCTAC & \\
\hline AB1658 & GCCACCATGGCTGATGATCACCATTAAGACC & virB9-2 \\
\hline AB1659 & GTTTCCGGCGTCTTTCAGCACCCTTC & \\
\hline AB1660 & GCCACCATGGCTGACGAAATAAGGGG & virB10 \\
\hline AB1661 & GCCTCACCGCATCACGAGGAAATA & \\
\hline \multicolumn{3}{|c|}{ Recombinant proteins } \\
\hline AB1703 & CACCATGAGCACAAATATTGGCGTACCAG & virB9-1 \\
\hline AB1704 & ACTAAGAGCCTGATTCACAACTTCTACACTCCTGC & \\
\hline AB1705 & CACCATGGCTGATGATCACATTAAGACCTTGAAC & virB9-2 \\
\hline AB1706 & TTTCCGGCGTCTTTCAGCACCCTTC & \\
\hline AB1707 & $\underline{\text { CACCATGGCTGACGAAATAAGGGGTTCTAG }}$ & virB10 \\
\hline AB1708 & CCTCACCGCATCACGAGGAAATACTACG & \\
\hline \multicolumn{3}{|l|}{ qPCR } \\
\hline AB1334 & AGATGCTGACTGGGGATGAG & msp5 \\
\hline AB1335 & TCGGCATCAACCAAGTACAA & \\
\hline${ }^{\mathrm{a} A B 1336}$ & CGTAGGTGAGTCTGATAGTGAAGG & \\
\hline
\end{tabular}

Underlined letters correspond to vector nucleotides added to enable directional cloning

${ }^{a}$ Probe labeled with Hexachloro-fluorescein (HEX) at the 5' end

green fluorescent endothelial cells were visualized (data not shown) using a Leica DMI 3000B inverted microscope equipped with a GFP filter specific for excitation and emission wavelengths of $470 / 40 \mathrm{~nm}$ and 525/50 respectively.

\section{Preparation of recombinant VirB9-1, VirB9-2 and VirB10 protein vaccines}

The open reading frames of A. phagocytophilum virB9-1, virB9-2 (devoid of their signal peptide) and virB10 genes were amplified by PCR using the iProof ${ }^{\mathrm{m}}$ High-Fidelity DNA polymerase (Bio-Rad). PCR primers were designed to incorporate specific vector sequences at the 5 'end of the genes to enable directional cloning into the pET101/ D-TOPO directional expression system (ThermoFisher Scientific) (Table 1). Purified PCR products were ligated into the pET101/D-TOPO vector and transformed into one shot TOP10 E. coli cells. Recombinant plasmids were recovered from individual colonies and virB9-1, virB9-2, and virB10 in frame sequences were confirmed by PCR, restriction enzyme and sequencing analysis. Recombinant clones contained the genes of interest followed by V5 epitope and 6X His tags. These constructs were retransformed into E. coli BL21 Star (DE3) cells (ThermoFisher Scientific), and grown overnight at $37^{\circ} \mathrm{C}$ in Luria-Bertani (LB) medium containing $1 \%$ glucose and $50 \mu \mathrm{g} / \mathrm{mL}$ carbenicillin until a cell density between $\mathrm{OD}_{600}$ of 3 to 5 was reached. Then, these cultures were switched to M9 minimal medium supplemented with glucose and carbenicillin at final concentrations of $1 \%$ and $50 \mu \mathrm{g} / \mathrm{mL}$, respectively, and induced with $0.5 \mathrm{mM}$ isopropyl $\beta$-D-thiogalactoside (IPTG) (SigmaAldrich) at $4{ }^{\circ} \mathrm{C}$ for an additional $28 \mathrm{~h}$. We switched to M9 minimal medium in order to limit bacterial growth and the depletion of substrates and cofactors required for protein synthesis [58]. Expression was induced at $4{ }^{\circ} \mathrm{C}$ to minimize protein aggregation and to reduce heat shock protease activity that could result in the formation of inclusion bodies.

Bacterial cells were harvested by centrifugation, and pellets were disrupted by sonication in sodium phosphate buffer pH $8.0\left(150 \mathrm{mM} \mathrm{NaCl}, 23.6 \mathrm{mM} \mathrm{Na}_{2} \mathrm{HPO}_{4}\right.$, 1.2 $\mathrm{M} \mathrm{NaH}_{2} \mathrm{PO}_{4}$ ) followed by centrifugation to fractionate the soluble and insoluble material. Soluble fractions containing the recombinant $6 \mathrm{X}$ His-tagged fusion proteins were purified using low density Nickel agarose bead columns (Gold Biotechnology). Eluted protein was concentrated using Centricon Plus-70 centrifugal filter units (EMD Millipore), and concentration determined using a Qubit protein assay kit (ThermoFisher Scientific). Verification of expression of soluble recombinant VirB9-1, Vir9-2, and VirB10 was performed by analysis of proteins on sodium dodecyl sulfate-polyacrylamide gel electrophoresis (SDS-PAGE) stained with GelCode Blue (ThermoFisher Scientific) and by Western blot analysis using a monoclonal mouse anti-His antibody (SignalChem).

\section{Anaplasma phagocytophilum cultivation}

Two cell lines were used for this work: the HL-60 human promyelocytic cells and the RF/6A cells derived from the retina choroid endothelium of a rhesus monkey (Macaca mulatta). HL-60 cells were used to propagate the human isolate Anaplasma phagocytophilum strain $\mathrm{HZ}$ [59], and the RF/6A endothelial cells were used for transfection experiments as described above. Uninfected- and $A$. phagocytophilum-infected cultures were maintained in RPMI 1640 medium (Hyclone) supplemented with $10 \%$ heat inactivated fetal bovine serum (FBS) (HyCLone), $2 \mathrm{mM} \mathrm{L-glutamine} \mathrm{(ThermoFisher}$ Scientific), $0.25 \% \mathrm{NaHCO}_{3}$ (Sigma-Aldrich) and $25 \mathrm{mM}$ HEPES (Sigma-Aldrich) and kept at $37^{\circ} \mathrm{C}$ in $5 \%$ carbon dioxide $\left(\mathrm{CO}_{2}\right)$ atmosphere.

\section{Preparation of host cell-free A. phagocytophilum}

For analysis of immunoblots, ELISA, and $\mathrm{T}$ cell responses, A. phagocytophilum organisms purified from infected HL-60 cells were used. For this, heavily infected cultures were transferred into sterile $2.0 \mathrm{ml}$ bead beater tubes (BioSpec Technologies) containing $1 \mathrm{~mm}$ diameter glass beads (BioSpec Technologies). Disruption of infected 
cells was performed in a Mini-Beadbeater (BioSpec Technologies) at $4800 \mathrm{rpm}$ for $10 \mathrm{~s}$. Cell lysates were transferred to $1.5 \mathrm{ml}$ tubes and centrifuged at $100 \mathrm{x} \mathrm{g}$ for $5 \mathrm{~min}$ at $4{ }^{\circ} \mathrm{C}$ to pellet cell debris. The supernatant was then carefully removed and filtered by passing it through a $2.0 \mu \mathrm{m}$ glass fiber syringe filter (Whatman). Bacteria were then pelleted by centrifugation at $11,000 \mathrm{x}$ g for $10 \mathrm{~min}$ at $4{ }^{\circ} \mathrm{C}$ and stored at $-20^{\circ} \mathrm{C}$ for further protein analysis work, DNA extraction and quantitative real-time PCR (qPCR) for quantitation of A. phagocytophilum GE.

\section{Experimental animals, immunization, and challenge}

Six-week-old female $\mathrm{C} 3 \mathrm{H} / \mathrm{HeN}$ mice were purchased from Charles River Laboratories and maintained under pathogen-free conditions and the veterinary care of the Animal Care Services (ACS) facility at the University of Florida.

Five groups (10 mice/group) were vaccinated in a prime-boost fashion. Briefly, mice received two intramuscular (IM) injections at 2-week intervals with $100 \mu \mathrm{g}$ of endotoxin-free plasmid DNA virB9-1, virB9-2, or virB10, a mixture of the three constructs, or $p c D N A 3.1 /$ CT-GFP empty vector. Two weeks after the last DNA immunization, the same groups received two subcutaneous (SC) injections at two-week intervals with $100 \mu \mathrm{g}$ of their respective purified recombinant VirB9-1, VirB9-2, or VirB10 proteins, a mixture of the three recombinant proteins, or Ovalbumin (InvivoGen) in $15 \mu \mathrm{g}$ of Quil-A adjuvant (Sergeant Adjuvants).

Two weeks after the last recombinant protein immunization, three mice from each group were randomly selected and euthanized for collection of serum samples and harvesting of their spleens to determine immune responses before challenge. Approximately $5 \mu \mathrm{l}$ serum was also collected from the remaining seven mice per group. These remaining seven mice per group were then challenged intraperitoneally (IP) with A phagocytophilum organisms isolated from $5.63 \times 10^{5}$ HL-60 cells ( $90 \%$ of the cells contained morulae) that were lysed by needle aspiration through $25 \mathrm{Ga}$ and $30 \mathrm{Ga}$ needles. Blood samples to determine bacterial load were collected starting 2 days post-challenge and every other day. Mice were euthanized at day 14 post-challenge, spleens were harvested, and serum samples collected.

\section{Antibody responses}

To determine sera specificity against $A$. phagocytophilum by indirect immunofluorescence assay (IFA), HL-60 cells ( $10^{4}$ cells per well) $80 \%$ infected with $A$. phagocytophilum $/ \mathrm{HZ}$ were fixed with acetone for $10 \mathrm{~min}$ at room temperature onto 12 well Teflon-coated microscope slides (Tekdon inc). Samples were blocked by adding $20 \mu \mathrm{l}$ of $5 \%$ bovine serum albumin (BSA) diluted in $1 \mathrm{X}$ phosphate-buffered saline (PBS) (Hyclone), incubated in a humidified chamber atmosphere at room temperature (RT) for $1 \mathrm{~h}$, and subsequently rinsed with wash buffer (0.05\% Tween 20 (Sigma-Aldrich) in 1X PBS). Sera from the three mice from each group were then combined and serially diluted $1: 80$ to $1: 81,920$. Ten $\mu$ l of serum were applied to each well in duplicate for each dilution, and incubated for $1 \mathrm{~h}$ at RT in a humidified chamber. After incubation, the sera were removed, and the slides washed five times for $5 \mathrm{~min}$. Ten $\mu \mathrm{l}$ of Alexa Fluor 568-goat anti-mouse IgG antibody (ThermoFisher Scientific) at a dilution of 1:1600 was applied to each well and incubated for $1 \mathrm{~h}$ at RT in a humidified chamber. The slides were washed as described above and mounted with ProLong Gold antifade reagent with DAPI (4',6-diamidino-2-phenylindole) (ThermoFisher Scientific) for visualization of fluorescent $A$. phagocytophilum inclusions.

Antibodies from these immunized mice were assessed by SDS-PAGE and immunoblotting using equal amounts $\left(10^{8}\right)$ of host cell-free bacteria. Membranes were incubated with sera at a dilution of 1:1000. Antibody binding was detected with the secondary antibody horseradish peroxidase-goat anti-mouse IgG (Sigma-Aldrich) at a final concentration of 1:100,000 and the SuperSignal West Femto substrate (ThermoFisher Scientific) as described by the manufacturer.

Sera collected from the ten rVirB-vaccinated mice and control group, before challenge, were tested by an enzyme-linked immunosorbent assay (ELISA) to measure the level of antibodies against A. phagocytophilum organisms. A 384-well MaxiSorp microtiter plate (Nunc) was coated overnight at $4{ }^{\circ} \mathrm{C}$ with host cell-free $A$. phagocytophilum organisms $\left(10^{8} /\right.$ well $)$ in $50 \mu \mathrm{l}$ of carbonate-bicarbonate buffer (Sigma-Aldrich). Next morning the wells were rinsed three times with wash buffer (1X PBS pH 7.3 MT-PBS; $150 \mathrm{mM} \mathrm{NaCl}, 15.9 \mathrm{mM}$ $\mathrm{Na}_{2} \mathrm{HPO}_{4}, 4 \mathrm{mM} \mathrm{NaH} \mathrm{PO}_{4}$ with $0.05 \%$ Tween 20) and blocked for $2 \mathrm{~h}$ at RT with $100 \mu \mathrm{l}$ of $1 \%$ bovine serum albumin BSA in MT-PBS. Blocking buffer was removed, wells were washed $3 X$ and then incubated with 1:150, 1:300, 1:600 and 1:1200 dilutions (35 $\mu \mathrm{l})$ of the sera from all the immunized and control mice for $2 \mathrm{~h}$ at RT with shaking. After incubation, the wells were washed three times and reacted with recombinant protein A/G-Alkaline phosphatase (Sigma-Aldrich) at a dilution of 1:5000 for 1 $h$ at RT with shaking. Color was developed using 4-Nitrophenyl phosphate (Sigma-Aldrich), and the optical densities of the reactions were measured using a microplate reader (Synergy HT Bio-Tek) at $405 \mathrm{~nm}$. Titers were expressed as the reciprocal of the highest dilution. Results were considered positive when the signal/cutoff value was above the mean $\mathrm{OD}_{405}$ response from seronegative samples ( $p c D N A 3.1 /$ Ovalbumin-vaccinated mice) plus the standard deviation (SD) multiplied by 1.923 (this factor 
was used based on the number of negative control samples) [60].

\section{Cellular immune responses}

Spleens were aseptically removed and transferred into $2.0 \mathrm{ml}$ safe-lock tubes (Eppendorf) containing one $5 \mathrm{~mm}$ stainless steel bead and homogenized in a TissueLyser II apparatus (Qiagen) for $2 \mathrm{~min}$ at $20 \mathrm{~Hz}$. The homogenate was then passed throughout a 70- $\mu \mathrm{m}$ nylon mesh (BD Falcon), resuspended in $5 \mathrm{ml}$ of sterile $\mathrm{H}_{2} \mathrm{O}$ to lyse red blood cells, and then brought to a final volume of $20 \mathrm{ml}$ by adding flow cytometry (FACS) buffer (Dulbecco's phosphate buffered saline (Sigma-Aldrich), 2\% FBS). Cells were then pelleted at $400 \mathrm{x} \mathrm{g}$ for $5 \mathrm{~min}$ at $4{ }^{\circ} \mathrm{C}$, stained with trypan blue, and enumerated using a Nexcelom Bioscience cellometer. Mouse splenocytes were cryopreserved in $1.0 \mathrm{ml}$ of freezing medium (90\% FBS, 10\% DMSO) [61].

Frozen splenic cell suspensions were thawed at $37^{\circ} \mathrm{C}$, resuspended in complete medium (CM) (RPMI 1640 medium (HyClone) supplemented with 10\% FBS, 0.25\% $\mathrm{NaHCO}_{3}$ (Sigma-Aldrich), $25 \mathrm{mM}$ HEPES (Sigma-Aldrich), $1 \mathrm{X}$ of non-essential amino acids (Sigma-Aldrich), and $1 \mathrm{X}$ of penicillin/streptomycin (penicillin 100Units/mL, streptomycin $100 \mu \mathrm{g} / \mathrm{mL}$ (Sigma-Aldrich)) and centrifuged at $400 \mathrm{x} \mathrm{g}$ for $5 \mathrm{~min}$ at room temperature. Pelleted splenic cells were resuspended in $\mathrm{CM}$, enumerated, and then cultured in round-bottom 96-well tissue culture plates at a concentration of $5 \times 10^{6}$ cells $/ \mathrm{ml}$ and stimulated with $5 \mu \mathrm{g} / \mathrm{ml}$ of host cell-free A. phagocyotphilum organisms (heat-killed at $65^{\circ} \mathrm{C}$ for $10 \mathrm{~min}$ ) or medium only (unstimulated control) in triplicate wells at $37^{\circ} \mathrm{C}$ in $5 \%$ carbon dioxide $\left(\mathrm{CO}_{2}\right)$ atmosphere. Spleen cells were harvested after $18 \mathrm{~h}$ of antigen stimulation followed by a four-hour incubation with $1 \mu \mathrm{g} / \mathrm{ml}$ ionomycin (eBioscience), $20 \mathrm{ng} / \mathrm{ml}$ phorbol 12-myristate (PMA), and $10 \mu \mathrm{g} / \mathrm{ml}$ of Brefeldin A (eBioscience).

For flow cytometry, cells were harvested and washed in FACS buffer and surface stained with fluorochrome-labeled antibodies specific for mouse CD4 (Alexa Fluor 700, clone: GK1.5) (eBioscience) and CD8 (Brilliant violet 510, clone: 53-6.7) (Biolegend) for $20 \mathrm{~min}$ on ice. In addition, intracellular cell staining was performed to detect intracellular cytokines. After cell surface marker staining, washed cells were fixed and permeabilized using an intracellular fixation and permeabilization buffer set (eBioscience) as per manufacturer's instructions. Lymphocytes were stained intracellularly with fluorochrome-labeled antibodies specific for mouse IFN- $\gamma$ (Brilliant violet 785, clone: XMG1.2, Biolegend) and IL-10 (PE, clone: JES5-16E3, eBioscience) for $20 \mathrm{~min}$ at room temperature. Cells were washed and resuspended in FACS buffer and 250,000 events were collected on a LSR Fortessa flow cytometer (BD Biosciences), and data analyzed using FlowJo software. The frequencies of antigen-specific $\mathrm{T}$ cells in the spleens from vaccinated and control mice were determined after the background staining of unstimulated cells in wells containing medium only was subtracted.

\section{Quantitative real-time PCR of blood}

DNA isolation from mouse blood was performed using the Quick-gDNA blood microprep kit (Zymo Research) as per manufacturer's instructions. The DNA concentration of each sample was determined using the Qubit dsDNA high sensitivity (HS) assay kit (Life Technologies) on a Qubit fluorometer (Life Technologies). Quantification of $A$. phagocytophilum genome equivalents (GE) was performed by qPCR with primers and a probe targeting the single copy gene msp5 (Table 1). Triplicate reactions from each sample per group at each time point were used. Reactions of $20 \mu \mathrm{L}$ containing $2 \mu \mathrm{L}$ of genomic DNA, 1X of LightCycler 480 probe master mix (Roche), $0.4 \mu \mathrm{M}$ forward and reverse primers and $0.2 \mu \mathrm{M}$ of probe were used for amplification in a LightCycler 580 real-time PCR instrument (Roche) with the following conditions, $95^{\circ} \mathrm{C}$ for $10 \mathrm{~min}$ and 45 cycles of $94{ }^{\circ} \mathrm{C}$ for $10 \mathrm{~s}$, and $60^{\circ} \mathrm{C}$ for $30 \mathrm{~s}$. Ten-fold serial dilutions of the pCR-TOPO vector carrying the A. phagocytophilum msp 5 gene were used for standard curve preparation, and the A. phagocytophilum GE number was calculated based on the standard curve. Results were normalized based on the volume of blood collected per animal at each time point. No template control and genomic DNA extracted from the blood of unchallenged mice were used as negative controls.

\section{Statistical analysis}

Data are expressed as Mean \pm SE or SD values. One way analysis of variance (ANOVA) with Dunnett's posttest were used to compare multiple tests groups to the control $p c D N A 3.1 /$ Ovalbumin vaccinated group and unpaired two-tailed $t$ test was used for comparison of two groups using Sigmaplot version 12 (Systat Software Inc., San Jose, CA), and graphics made with GraphPad Prism (GraphPad Software Inc., La Jolla, CA). Data from T cell immune responses were square-root transformed to normalize variances.

\section{Abbreviations \\ CMV: Cytomegalovirus; ELISA: Enzyme-linked immunosorbent assay; GE: Genome equivalents; HGA: Human granulocytic anaplasmosis; \\ IFA: Immunofluorescence Assay; IFN- $\gamma$ : Interferon-gamma; IL-10: Interleukin- 10; SDS-PAGE: Sodium dodecyl sulfate polyacrylamide gel electrophoresis; T4SS: Type 4 Secretion System}

\section{Acknowledgments}

We want to thank Dr. Soojung Seo Ph.D. for her technical assistance in preparing the DNA vaccine constructs. 


\section{Funding}

This work was supported by the National Institute of Allergy and Infectious Diseases (NIH) U54Al057156, through a subcontract from the University of Texas Medical Branch (UTMB) and David Walker M.D. (PI). The funding body had no role in the study design, collection, analysis, interpretation of data and in writing the manuscript.

\section{Availability of data and materials}

The datasets used and/or analyzed during the current study available from the corresponding author on reasonable request.

\section{Authors' contributions}

AFB conceived the project, supervised the research and contributed to data analysis and writing of the manuscript. FLC, authored this manuscript, conceived and carried out this project experimental design, acquired analyzed and interpreted all the data. DWP critically revised the manuscript and contributed to its writing. $\mathrm{CH}$ participated in sample collection from mice, specifically spleen collection, preparation of splenic cell suspensions and provided advice on the acquisition and analysis of $T$ cell responses from FACS experiments. AML assisted with the preparation and purification of the recombinant proteins and performed Western Immunoblots. All authors read and approved the final manuscript.

\section{Ethics approval and consent to participate}

All animal care and procedures were in accordance with institutional policies for animal health and well-being and approved by University of Florida Institutional Animal Care and Use Committee (IACUC).

The cell lines used in this study were obtained from the ATCC Cell Biology Collection (HL-60, ATCC CRL-240; RF/6A, ATCC CRL-1780).

\section{Consent for publication}

Not applicable.

\section{Competing interests}

The authors declare that they have no competing interests.

\section{Publisher's Note}

Springer Nature remains neutral with regard to jurisdictional claims in published maps and institutional affiliations.

\section{Received: 26 March 2018 Accepted: 16 November 2018}

Published online: 18 December 2018

\section{References}

1. Palmer GH, McElwain TF. Molecular basis for vaccine development against anaplasmosis and babesiosis. Vet Parasitol. 1995:57(1-3):233-53.

2. Albarrak SM, Brown WC, Noh SM, Reif KE, Scoles GA, Turse JE, Norimine J, Ueti MW, Palmer GH. Subdominant antigens in bacterial vaccines: AM779 is subdominant in the Anaplasma marginale outer membrane vaccine but does not associate with protective immunity. PLoS One. 2012;7(9):e46372. https://doi.org/10.1371/journal.pone.0046372.

3. Ducken DR, Brown WC, Alperin DC, Brayton KA, Reif KE, Turse JE, Palmer GH, Noh SM. Subdominant outer membrane antigens in Anaplasma marginale: conservation, antigenicity, and protective capacity using recombinant protein. PLoS One. 2015;10(6):e0129309. https:/doi.org/10.1371/journal.pone.0129309.

4. Stuen S, Okstad W, Artursson K, Al-Khedery B, Barbet A, Granquist EG. Lambs immunized with an inactivated variant of Anaplasma phagocytophilum. Acta Vet Scand. 2015;57:40. https://doi.org/10.1186/s13028-015-0131-1.

5. Orr MT, Ireton GC, Beebe EA, Huang PW, Reese VA, Argilla D, Coler RN, Reed SG. Immune subdominant antigens as vaccine candidates against Mycobacterium tuberculosis. J Immunol. 2014;193(6):2911-8. https://doi.org/ 10.4049/jimmunol.1401103.

6. Lopez JE, Palmer GH, Brayton KA, Dark MJ, Leach SE, Brown WC Immunogenicity of Anaplasma marginale type IV secretion system proteins in a protective outer membrane vaccine. Infect Immun. 2007;75(5):2333-42. https://doi.org/10.1128/IAl.00061-07.

7. Esmaeili D, Khaledi A, Bahador A. The proteins of type IV secretion system as promising candidates for Helicobacter pylori vaccine. Pharmaceut Reg Affairs. 2015;4(148):2. https://doi.org/10.4172/2167-7689.1000148.
8. Gillespie JJ, Brayton KA, Williams KP, Diaz MA, Brown WC, Azad AF, Sobral BW Phylogenomics reveals a diverse Rickettsiales type IV secretion system. Infect Immun. 2010;78(5):1809-23. https://doi.org/10.1128/IAl.01384-09.

9. Araujo FR, Costa CM, Ramos CA, Farias TA, Souza II, Melo ES, Elisei C, Rosinha GM, Soares CO, Fragoso SP, Fonseca AH. lgG and IgG2 antibodies from cattle naturally infected with Anaplasma marginale recognize the recombinant vaccine candidate antigens VirB9, VirB10, and elongation factor-Tu. Mem Inst Oswaldo Cruz. 2008;103(2):186-90. https://doi.org/10. 1590/S0074-02762008000200010.

10. Lopez JE, Beare PA, Heinzen RA, Norimine J, Lahmers KK, Palmer GH, Brown WC. High-throughput identification of T-lymphocyte antigens from Anaplasma marginale expressed using in vitro transcription and translation. J Immunol Methods. 2008;332(1-2):129-41. https://doi.org/10.1016/j.jim.2007.12.018.

11. Vidotto MC, Venancio EJ, Vidotto O. Cloning, sequencing and antigenic characterization of rVirB9 of Anaplasma marginale isolated from Parana state, Brazil. Genet Mol Res. 2008;7(2):460-6.

12. Junior DS G, Araujo FR, Almeida Junior NF, Adi SS, Cheung LM, Fragoso SP, Ramos CA, Oliveira RH, Santos CS, Bacanelli G, Soares CO, Rosinha GM, Fonseca $\mathrm{AH}$. Analysis of membrane protein genes in a Brazilian isolate of Anaplasma marginale. Mem Inst Oswaldo Cruz. 2010;105(7):843-9. https:// doi.org/10.1590/S0074-02762010000700001.

13. Sutten EL, Norimine J, Beare PA, Heinzen RA, Lopez JE, Morse K, Brayton KA, Gillespie JJ, Brown WC. Anaplasma marginale type IV secretion system proteins VirB2, VirB7, VirB11, and VirD4 are immunogenic components of a protective bacterial membrane vaccine. Infect Immun. 2010;78(3):1314-25. https://doi.org/10.1128/IAl.01207-09.

14. Morse K, Norimine J, Hope JC, Brown WC. Breadth of the CD4 ${ }^{+} \mathrm{T}$ cell response to Anaplasma marginale VirB9-1, VirB9-2 and VirB10 and MHC class II DR and DQ restriction elements. Immunogenetics. 2012;64(7):507-23. https://doi.org/10.1007/s00251-012-0606-4.

15. Morse K, Norimine J, Palmer GH, Sutten EL, Baszler TV, Brown WC. Association and evidence for linked recognition of type IV secretion system proteins VirB9-1, VirB9-2, and VirB10 in Anaplasma marginale. Infect Immun. 2012:80(1):215-27. https://doi.org/10.1128/IAl.05798-11.

16. Zhao L, Mahony D, Cavallaro AS, Zhang B, Zhang J, Deringer JR, Zhao CX, Brown WC, Yu C, Mitter N, Middlelberg AP. Immunogenicity of outer membrane proteins VirB9-1 and VirB9-2, a novel nanovaccine against Anaplasma marginale. PLoS One. 2016;1 1(4):e0154295. https://doi.org/10. 1371/journal.pone.0154295.

17. Felek $S$, Huang $H$, Rikihisa $Y$. Sequence and expression analysis of virB9 of the type IV secretion system of Ehrlichia canis strains in ticks, dogs, and cultured cells. Infect Immun. 2003;71(10):6063-7. https://doi.org/10.1128/IAI. 71.10.6063-6067.2003

18. Al-Khedery B, Lundgren AM, Stuen S, Granquist EG, Munderloh UG, Nelson CM, Alleman AR, Mahan SM, Barbet AF. Structure of the type IV secretion system in different strains of Anaplasma phagocytophilum. BMC Genomics. 2012;13:678. https://doi.org/10.1186/1471-2164-13-678.

19. Niu H, Rikihisa Y, Yamaguchi M, Ohashi N. Differential expression of VirB9 and VirB6 during the life cycle of Anaplasma phagocytophilum in human leucocytes is associated with differential binding and avoidance of lysosome pathway. Cell Microbiol. 2006;8(3):523-34 doi.org/10.1111/j.14625822.2005.00643.x

20. Dugat T, Lagree AC, Maillard R, Boulouis HJ, Haddad N. Opening the black box of Anaplasma phagocytophilum diversity: current situation and future perspectives. Front Cell Infect Microbiol. 2015;5:61. https://doi.org/10.3389/ fcimb.2015.00061.

21. Brown WC. Adaptive immunity to Anaplasma pathogens and immune dysregulation: implications for bacterial persistence. Comp Immunol Microbiol Infect Dis. 2012;35(3):241-52. https://doi.org/10.1016/j.cimid.2011.12.002.

22. Anderson RJ, Hannan CM, Gilbert SC, Laidlaw SM, Sheu EG, Korten S, Sinden R, Butcher GA, Skinner MA, Hill AV. Enhanced CD8+ T cell immune responses and protection elicited against Plasmodium berghei malaria by prime boost immunization regimens using a novel attenuated fowlpox virus. J Immunol. 2004;172(5):3094-100. https://doi.org/10.4049/jimmunol.172.5.3094.

23. McConkey SJ, Reece WH, Moorthy VS, Webster D, Dunachie S, Butcher G, Vuola JM, Blanchard TJ, Gothard P, Watkins K, Hannan CM, Everaere S, Brown K, Kester KE, Cummings J, Williams J, Heppner DG, Pathan A, Flanagan K, Arulananthanm N, Roberts MT, Roy M, Smith GL, Scheneider J, Peto T, Sinden RE, Gilbert SC, Hill AV. Enhanced T-cell immunogenicity of plasmid DNA vaccines boosted by recombinant modified vaccinia virus Ankara in humans. Nat Med. 2003:9(6):729-35. 
24. Moorthy VS, Imoukhuede EB, Keating S, Pinder M, Webster D, Skinner MA, Gilbert SC, Walraven G, Hill AV. Phase 1 evaluation of 3 highly immunogenic prime-boost regimens, including a 12-month reboosting vaccination, for malaria vaccination in Gambian men. J Infect Dis. 2004;189(12):2213-9 doi.org/10.1086/421118.

25. Moorthy VS, Pinder M, Reece WH, Watkins K, Atabani S, Hannan C, Bojang K, McAdam KP, Schneider J, Gilbert S, Hill AVS. Safety and immunogenicity of DNA/modified vaccinia virus Ankara malaria vaccination in African adults. J Infect Dis. 2003;188(8):1239-44 doi.org/10.1086/378515.

26. McShane H. Prime-boost immunization strategies for infectious diseases. Curr Opin Mol Ther. 2002;4(1):23-7.

27. McShane H, Behboudi S, Goonetilleke N, Brookes R, Hill AV. Protective immunity against Mycobacterium tuberculosis induced by dendritic cells pulsed with both $\mathrm{CD}^{+}$- and $\mathrm{CD} 4^{+}-\mathrm{T}$-cell epitopes from antigen $85 \mathrm{~A}$. Infect Immun. 2002;70(3):1623-6 doi: 10.1128/IAI.70.3.1623-1626.2002.

28. Woodland DL. Jump-starting the immune system: prime-boosting comes of age. Trends Immunol. 2004;25(2):98-104 doi.org/10.1016/j.it.2003.11.009.

29. Walker $\mathrm{DH}$. The realities of biodefense vaccines against Rickettsia. Vaccine. 2009;27(Suppl 4):D52-5. https://doi.org/10.1016/j.vaccine.2009.07.045.

30. Nyika A, Barbet AF, Burridge MJ. Mahan SM. DNA vaccination with map1 gene followed by protein boost augments protection against challenge with Cowdria ruminantium, the agent of heartwater. Vaccine. 2002;20(7-8): 1215-25 doi.org/10.1016/S0264-410X(01)00430-3.

31. Crocquet-Valdes PA, Thirumalapura NR, Ismail N, Yu X, Saito TB, Stevenson HL, Pietzsch CA, Thomas S, Walker DH. Immunization with Ehrlichia P28 outer membrane proteins confers protection in a mouse model of ehrlichiosis. Clin Vaccine Immunol. 2011;18(12):2018-25. https://doi.org/10. 1128/CVI.05292-11.

32. Palacios C, Torioni de Echaide S, Mattion N. Evaluation of the immune response to Anaplasma marginale MSP5 protein using a HSV-1 amplicon vector system or recombinant protein. Res Vet Sci. 2014;97(3):514-20. https://doi.org/10.1016/j.rvsc.2014.10.005.

33. Binley JM, Sanders RW, Clas B, Schuelke N, Master A, Guo Y, Kajumo F, Anselma DJ, Maddon PJ, Olson WC, Moore JP. A recombinant human immunodeficiency virus type 1 envelope glycoprotein complex stabilized by an intermolecular disulfide bond between the gp120 and gp41 subunits is an antigenic mimic of the trimeric virion-associated structure. J Virol. 2000;74(2):627-43. https://doi.org/10.1128/JVI.74.2.627-643.2000.

34. Huang CJ, Peng HL, Cheng CY. Improving antigenicity of the recombinant hepatitis $C$ virus core protein via random mutagenesis. J Biomed Biotechnol. 2011;2011:359042. https://doi.org/10.1155/2011/359042.

35. Fonjungo PN, Stuber D, McBride JS. Antigenicity of recombinant proteins derived from rhoptry-associated protein 1 of Plasmodium falciparum. Infect Immun. 1998;66(3):1037-44.

36. Cavanagh DR, Kocken CH, White JH, Cowan GJ, Samuel K, Dubbeld MA, Voorberg-van der Wel A, Thomas AW, McBride JS, Arnot DE. Antibody responses to a novel Plasmodium falciparum merozoite surface protein vaccine correlate with protection against experimental malaria infection in Aotus monkeys. PLoS One. 2014;9(1):e83704. https://doi.org/10.1371/journal.pone.0083704.

37. Cavanagh DR, McBride JS. Antigenicity of recombinant proteins derived from Plasmodium falciparum merozoite surface protein 1. Mol Biochem Parasitol. 1997;85(2):197-211.

38. Ge Y, Rikihisa Y. Identification of novel surface proteins of Anaplasma phagocytophilum by affinity purification and proteomics. J Bacteriol. 2007; 189(21):7819-28. https://doi.org/10.1128/JB.00866-07.

39. Ojogun N, Kahlon A, Ragland SA, Troese MJ, Mastronunzio JE, Walker NJ, Viebrock L, Thomas RJ, Borjesson DL, Fikrig E, Carlyon JA. Anaplasma phagocytophilum outer membrane protein A interacts with sialylated glycoproteins to promote infection of mammalian host cells. Infect Immun. 2012;80(11):3748-60. https://doi.org/10.1128/IAl.00654-12 .

40. Kahlon A, Ojogun N, Ragland SA, Seidman D, Troese MJ, Ottens AK, Mastronunzio JE, Truchan HK, Walker NJ, Borjesson DL, Fikrig E, Carlyon JA. Anaplasma phagocytophilum Asp14 is an invasin that interacts with mammalian host cells via its $C$ terminus to facilitate infection. Infect Immun. 2013;81(1):65-79. https://doi.org/10.1128/IAl.00932-12.

41. Chandran V, Fronzes R, Duquerroy S, Cronin N, Navaza J, Waksman G. Structure of the outer membrane complex of a type IV secretion system. Nature. 2009;462(7276):1011-5. https://doi.org/10.1038/nature08588.

42. Seidman D, Ojogun N, Walker NJ, Mastronunzio J, Kahlon A, Hebert KS, Karandashova S, Miller DP, Tegels BK, Marconi RT, Fikrig E, Borjesson DL, Carlyon JA. Anaplasma phagocytophilum surface protein AipA mediates invasion of mammalian host cells. Cell Microbiol. 2014;16(8):1133-45. https://doi.org/10.1111/cmi.12286.

43. Seidman D, Hebert KS, Truchan HK, Miller DP, Tegels BK, Marconi RT, Carlyon JA. Essential domains of Anaplasma phagocytophilum invasins utilized to infect mammalian host cells. PLoS Pathog. 2015;11(2):e1004669 doi.org/10.1371/journal.ppat.1004669.

44. Akkoyunlu M, Fikrig E. Gamma interferon dominates the murine cytokine response to the agent of human granulocytic ehrlichiosis and helps to control the degree of early rickettsemia. Infect Immun. 2000;68(4):1827-33. https://doi.org/10.1128/IAl.68.4.1827-1833.2000.

45. Bussmeyer U, Sarkar A, Broszat K, Ludemann T, Moller S, van Zandbergen G, Bogdan C, Behnen M, Dumler JS, von Loewenich FD, Solbach W, Laskay T. Impairment of gamma interferon signaling in human neutrophils infected with Anaplasma phagocytophilum. Infect Immun. 2010;78(1):358-63. https://doi.org/10.1128/IAl.01005-09.

46. Sun W, IJdo JW, Telford SR 3rd, Hodzic E, Zhang Y, Barthold SW, Fikrig E. Immunization against the agent of human granulocytic ehrlichiosis in a murine model. J Clin Invest. 1997;100(12):3014-8. https:/doi.org/10.1172/JCl119855.

47. Birkner K, Steiner B, Rinkler C, Kern Y, Aichele P, Bogdan C, von Loewenich FD. The elimination of Anaplasma phagocytophilum requires CD4 ${ }^{+} \mathrm{T}$ cells, but is independent of Th1 cytokines and a wide spectrum of effector mechanisms. Eur J Immunol. 2008;38(12):3395-410.

48. Martin ME, Caspersen K, Dumler JS. Immunopathology and ehrlichial propagation are regulated by interferon-gamma and interleukin-10 in a murine model of human granulocytic ehrlichiosis. Am J Pathol. 2001; 158(5):1881-8.

49. Couper KN, Blount DG, Riley EM. IL-10: the master regulator of immunity to infection. J Immunol. 2008;180(9):5771-7 doi.org/10.4049/jimmunol.180.9.5771.

50. Martin ME, Bunnell JE, Dumler JS. Pathology, immunohistology, and cytokine responses in early phases of human granulocytic ehrlichiosis in a murine model. J Infect Dis. 2000;181(1):374-8 doi.org/10.1086/315206.

51. Flores-Garcia Y, Rosales-Encina JL, Satoskar AR, Talamas-Rohana P. IL-10-IFNgamma double producers $C D 4^{+} \mathrm{T}$ cells are induced by immunization with an amastigote stage specific derived recombinant protein of Trypanosoma cruzi. Int J Biol Sci. 2011;7(8):1093-100.

52. Dumler JS, Barat NC, Barat CE, Bakken JS. Human granulocytic anaplasmosis and macrophage activation. Clin Infect Dis. 2007;45(2):199-204 doi.org/10. 1086/518834.

53. Davies RS, Madigan JE, Hodzic E, Borjesson DL, Dumler JS. Dexamethasoneinduced cytokine changes associated with diminished disease severity in horses infected with Anaplasma phagocytophilum. Clin Vaccine Immunol. 2011;18(11):1962-8. https://doi.org/10.1128/CVl.05034-11.

54. Walker DH, Dumler JS. The role of CD8 T lymphocytes in rickettsial infections. Semin Immunopathol. 2015;37(3):289-99. https://doi.org/10.1007/ s00281-015-0480-x.

55. Dumler JS, Trigiani ER, Bakken JS, Aguero-Rosenfeld ME, Wormser GP. Serum cytokine responses during acute human granulocytic ehrlichiosis. Clin Diagn Lab Immunol. 2000;7(1):6-8.

56. Cyktor JC, Turner J. Interleukin-10 and immunity against prokaryotic and eukaryotic intracellular pathogens. Infect Immun. 2011;79(8):2964-73. https://doi.org/10.1128/IAl.00047-11.

57. Pedra JH, Sutterwala FS, Sukumaran B, Ogura Y, Qian F, Montgomery RR, Flavell RA, Fikrig E. ASC/PYCARD and caspase-1 regulate the IL-18/IFNgamma axis during Anaplasma phagocytophilum infection. J Immunol. 2007; 179(7):4783-91 doi.org/10.4049/jimmunol.179.7.4783.

58. Sorensen HP, Mortensen KK. Soluble expression of recombinant proteins in the cytoplasm of Escherichia coli. Microb Cell Factories. 2005;4(1):1. https://doi.org/10.1186/1475-2859-4-1.

59. Rikihisa Y, Zhi N, Wormser GP, Wen B, Horowitz HW, Hechemy KE. Ultrastructural and antigenic characterization of a granulocytic ehrlichiosis agent directly isolated and stably cultivated from a patient in New York state. J Infect Dis. 1997;175(1):210-3.

60. Frey A, Di Canzio J. Zurakowski D. a statistically defined endpoint titer determination method for immunoassays. J Immunol Methods. 1998; 221(1-2):35-41 doi.org/10.1016/S0022-1759(98)00170-7.

61. Gad E, Rastetter L, Herendeen D, Curtis B, Slota M, Koehniein M, Disis N. Optimizing the cryopreservation of murine splenocytes for improved antigen-specific T cell function in ELISPOT. J Immunother Cancer. 2013;1(Suppl 1):P211. https://doi.org/10.1186/2051-1426-1-S1-P211. 